\title{
Teaching and research in forest ecology at UNB, 1942 to present
}

\author{
by Mark R. Roberts ${ }^{1}$
}

\begin{abstract}
The purposes of this paper are to review the history of forest ecology courses at the University of New Brunswick (UNB) in relation to the social context, summarize recent developments in forest ecology research at UNB, and identify critical areas for future research. Based on the UNB Undergraduate Calendar (1942 to present), the first forest ecology course was offered in 1957. Until the 1980s, forest ecology courses were generally related to silviculture and forest production. Since then, courses reflected increasing public concern with biodiversity and sustainable forest management. Research in the Forest Ecology Laboratory at UNB has emphasized forest ecosystem response to disturbance, including tree regeneration and herbaceous-layer recovery following silvicultural treatments. From this work, a disturbance severity model was developed for characterizing any kind of disturbance. Future research is needed to test the model across additional disturbance types, particularly new silvicultural treatments that are being used in forest ecosystem management.
\end{abstract}

Key words: teaching, forest ecology, research, disturbance, herbaceous layer, biodiversity, sustainable forest management, ecosystem management

\section{RÉSUMÉ}

Cet article vise à effectuer un historique des cours décologie forestière à l'Université du Nouveau-Brunswick (UNB) en fonction du contexte social, à constituer un sommaire des récents développements en recherche dans le domaine de lécologie forestière à l'UNB et à identifier les principaux domaines de recherche de l'avenir. Selon l'horaire des cours de baccalauréat de l'UNB (de 1942 à ce jour), les premiers cours décologie forestière ont été offerts en 1957. Les cours décologie forestières ont été, jusque dans les 1980, généralement reliés à la sylviculture et à la production forestière. Depuis lors, les cours reflètent l'intérêt croissant du public pour la biodiversité et l'aménagement forestier durable. Les recherches effectuées au Laboratoire décologie forestière de l'UNB ont mis en évidence les réactions de l'écosystème forestier suite à une perturbation, ainsi que la régénération des arbres et de la reconstitution du couvert herbacé à la suite de traitements sylvicoles. À partir de ces travaux, un modèle de limportance de la perturbation a été mis au point afin de caractériser toute forme de perturbation. Des travaux de recherche seront entrepris pour tester le modèle pour d’autres types de perturbation, en particulier les nouveaux traitements sylvicoles utilisés en gestion des écosystèmes forestiers.

Mots clés : enseignement, écologie forestière, recherche, perturbation, couvert herbacé, biodiversité, aménagement forestier durable, gestion des écosystèmes

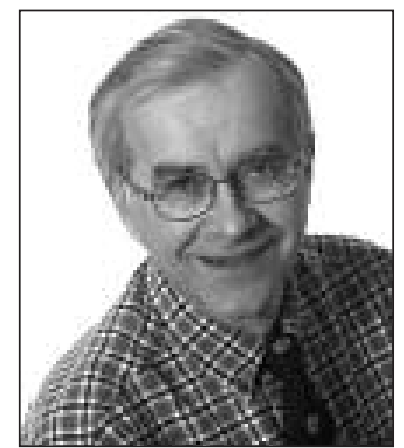

Mark R. Roberts

\section{Introduction}

Forest ecology is the basis for all management activities that we do in the forest environment, whether it is for the purpose of resource utilization or conservation. The particular way in which ecological principles are applied, however, depends upon the philosophical context in which the work is carried out. Changes in forest ecology teaching and research at the University of New Brunswick (UNB) over time reflect shifts in social values and forest management philosophies. The objectives of this paper are to review the history of forest ecology teaching at UNB with respect to changes in the social context surrounding the forestry profession and to summarize research in the
Forest Ecology Laboratory during my tenure at UNB (1983 to present). I conclude with thoughts on possible future directions for forest ecology research.

\section{The History of Forest Ecology Teaching at UNB}

To establish the early history of course offerings, I reviewed the UNB Undergraduate Calendar for every year from 1942 to 1983 . Calendars previous to 1942 were not available so I was not able to determine if there were any forest ecology courses before then. The course offerings in the Faculty in the 1940s were limited to silviculture, forest management, mensuration, forest protection and wood products, reflecting a strong emphasis on wood production. Thus, it is not likely that there was a forest ecology course in the curriculum before 1942 .

The first specific forest ecology course was offered by Prof. $\mathrm{H}$. Douglas Long in the third year of the curriculum from 1957 to 1962 . The course description reads: "An elementary course dealing with the effects of environmental factors on

${ }^{1}$ Professor, Faculty of Forestry, University of New Brunswick, P.O. Box 44555, Fredericton, New Brunswick E3B 6C2. E-mail: roberts@unb.ca. 
the growth, health and vigour of forests and forest trees." In 1962, this course was replaced by a fifth-year course, also taught by Prof. Long, with the course description, "The study of trees and forest vegetation in relation to environment, with emphasis on applications in forestry." G.R. Powell (Professor Emeritus) recalls that as part of the course, students made extensive ground vegetation analyses of different parts of the UNB Woodlot. This course was in the calendar until 1972. There was also a graduate course in forest ecology taught by Prof. Long from 1957 to 1961. Its emphasis was on vegetation sampling and quantitative plant ecology.

In 1973, the forest ecology course changed from the third to the fourth year of the curriculum. It was taught by several instructors in succession until 1983. In 1975, the lengthy course description included mention of ecological processes, such as production and decomposition. In 1979, the description changed to this brief statement: "Applications of the principles of ecology to the forest situation with special reference to the regulation of forest dynamics." There was also a fifthyear course in 1973, taught by G.F. Weetman. Also in 1973, a new course titled "Forest Botany," taught by G.R. Powell, appeared. It included silvics, plant identification and basic plant life histories. The forest botany course, in modified form and with various titles, has continued to the present day.

I took over the fourth-year ecology course in 1983 and taught it until 1988. In 1986, a second-year course was added, which I also taught. In 1989, these two courses were replaced by a single course, offered in the third year. This course continued until 1994, when it was split into two separate courses, one on population ecology (taught by D.T.W. Quiring) and the second on communities and ecosystems (taught by me). These two courses were recombined in 2005 (taught by D.T.W. Quiring and me). Also, between 1994 and 2002, two new ecology courses, "Cycles and Flows" and "Forest Ecology Practicum," taught by P. Arp and me, respectively, were included in the third year. In the practicum course, I addressed topical issues in forestry, including green certification, biodiversity management, invasive species and ecosystem management, among others. In 2005, a course on biodiversity and ecosystem management was added in the fourth year and continues to the present.

Several interesting observations emerged during my review of the course history. First, it is not surprising that there were initially few course offerings in forest ecology and the first course appeared as late as 1957, given that ecology was first recognized as a distinct discipline in the late 1800s and only in the past three or four decades has been recognized as a major branch of biological science (Kimmins 2004).

Second, forest ecology has been offered in every year of the curriculum except the first year at some point during the past $60+$ years. Why has the scheduling of this course changed so dramatically and so frequently? By definition, ecology is the science of the interrelationships of organisms with one another and with their environment. By its nature, ecology is an integrative discipline. Any student entering a basic forest ecology course, therefore, should have some knowledge of the organisms that make up the forest ecosystem and their physical environment. Without this basic knowledge, what will the students integrate? In the second year of the curriculum at UNB, the students are still taking basic courses in soils, silvics, plant identification, and other basic physical and biological sciences. To offer forest ecology in the second year, before the students have an adequate grasp of the basic ecosystem components, does not make sense. By the same token, forest ecology is the precursor to courses in silviculture, conservation and forest management in later years, where ecological concepts are applied. To delay forest ecology until the fourth or fifth year is counterintuitive. Thus, the basic forest ecology course is ideally positioned in the third year. This is where Prof. Long first taught the course in 1957 and where the course is currently offered.

Third, the course descriptions reflect changes in the prevailing philosophy surrounding forestry since the 1940s. Until the late 1980s, the forest ecology courses focused on forest production, with emphasis on tree regeneration, silvics, tree growth and density relationships and forest dynamics. Ecological processes were mentioned in the 1970s, but chiefly as related to production. If ground-layer vegetation was addressed, it was considered as competing vegetation or as indicators of site conditions for tree growth. One exception was Prof. Long's analyses of ground vegetation in 1962 to 1972. Prof. Long was ahead of his time! Since the 1990s, the ecology courses reflect increasing interest in biodiversity, ecologically sustainable forest management and green certification. To place the course history in this philosophical context, I have reviewed the changes in public concerns and social values in relation to forestry in the following section.

\section{The Historical Context}

Forest production was the main concern in forestry for at least the first three-quarters of the $20^{\text {th }}$ century. This emphasis was apparent during the early years of the Faculty, as reflected in the course offerings and the absence of forest ecology courses. From 1957 through the 1970s, the forest ecology courses primarily played a supporting role in silviculture and forest management. Apparently, production forestry was still the primary focus of the Faculty.

With the advent of the forest site classification project in New Brunswick in the 1980s (Bowling and Zelazny 1992), research and education in forest ecology at UNB took on an added dimension. The value of herbaceous-layer vegetation as an indicator of site conditions was explicitly recognized and aspects of site classification were incorporated into courses in forest ecology, silvics and dendrology, silviculture and soils.

Beginning in the 1980s, there was a rise in public concern over biodiversity. The impetus toward biodiversity conservation culminated in the 1990s with numerous global initiatives, including the United Nations Conference on the Environment and Development in 1992 and the Paris Declaration of the Tenth World Forestry Congress in 1991. Governments and forestry groups in North America responded by developing strategies for incorporating biodiversity considerations into forest management (e.g., SAF 1991; CFA 1992; CCFM 1994, 1995). See Battles et al. (2001), Burton et al. (1992) and Roberts and Gilliam (1995) for further discussion of issues related to biodiversity and forest management.

Public focus on biodiversity soon shifted toward ecologically sustainable forest management. Considerable work was done in the 1990s and into the $21^{\text {st }}$ century to develop criteria and indicators of sustainable forest management (e.g., NRCan 2003). Research and policy development in this area continues today. 
Along with concern for biodiversity and sustainable forest management came green certification, which has put pressure on forest industry to demonstrate that its management activities are consistent with principles of ecologically sustainable forest management. Beginning in the early 1990s, forest ecology across North America took on a new direction as need for the scientific basis of sustainable forest management and green certification increased. In our Faculty at UNB, the number and diversity of course offerings in forest ecology increased in 1994 in response to this change in philosophy.

Most recently, the public has become concerned with the economic sustainability of forest-dependent communities (e.g., CCFM 2007). The gist of the concern here is that layoffs of workers in the forestry sector and mill closures have caused economic hardship in many communities across Canada and elsewhere. Although resolution of this problem lies partly in the realms of sociology, economics and politics, ecological principles that have been developed to date must be heeded if we are to achieve economic and ecological sustainability.

\section{Recent Research in Forest Ecology at UNB}

Since I established the Forest Ecology Laboratory at UNB in 1983, the research within this lab has taken three major lines: 1) identifying mechanisms of tree regeneration in harvested stands, 2) assessing the response of the herbaceous layer to forest harvesting, and 3) characterizing the nature of disturbance, with particular emphasis on forest harvesting.

\section{Mechanisms of tree regeneration in harvested stands}

In early work, we used controlled field experiments to assess regeneration of woody species under different environmental conditions. Removal of the forest floor in clearcuts in northern hardwood stands resulted in higher seed germination and seedling survival of white and yellow birch (Betula papyrifera Marsh. and Betula alleghaniensis Britt.) (Roberts and Dong 1993). McInnis and Roberts (1995) assessed light, temperature and moisture conditions under slash loads representative of full-tree and tree-length harvests. Seedling losses were attributed to higher extreme soil surface temperatures on organic surfaces and areas exposed to direct sunlight in both studies. As long as slash is not too dense, it is beneficial to regeneration. Adequate slash to protect new seedlings is not likely to occur in full-tree harvests.

\section{Response of the herbaceous layer to disturbance}

The herbaceous layer was an early focus of the Forest Ecology Lab. In initial work, we examined vegetation-environment relationships at the landscape scale in New Brunswick (Godin and Roberts 1994). Roberts and Wuest (1999) was one of the first studies to quantitatively assess vegetation-environment relationships at the regional scale anywhere and the first quantitative analysis in eastern Canada. These two works are being used as the basis of the NB ecological land classification system (New Brunswick Department of Natural Resources, unpublished document on CD-ROM).

A major portion of the research effort in the Forest Ecology Lab since 1990 has been directed toward documenting effects of forest harvesting disturbance on the herbaceous layer and identifying the mechanisms of response. In an early review paper, we pointed out the pitfalls of focusing exclusively on species diversity and recommended instead carefully documenting changes in individual species after harvesting (Roberts and Gilliam 1995). In early fieldwork, we identified approximately 20 species of the herbaceous layer that declined through the first two years after clearcutting, with the greatest declines occurring in areas that were mechanically scarified and planted (Roberts and Zhu 2002). Our work has been incorporated into forest management guidelines (Betts and Forbes 2005).

To determine changes in the herbaceous layer over a longer term, we constructed chronosequences of stands aged 50 to 100 years, including the oldest plantations available in southern New Brunswick (Ramovs and Roberts 2003, 2005). Such studies documenting long-term changes in the herbaceous layer are rare. We compared naturally regenerated old fields and clearcuts to forest plantations and identified mechanisms of herbaceous-layer recovery under differing disturbance scenarios. Old-field plantations, because of their unique disturbance history, contained the lowest abundance of species characteristic of forest habitats, although plantations on cutovers were also relatively low. Life forms with low growth and reproductive rates (i.e., geophytes, chamaephytes and rosette hemicryptophytes) were most affected by harvesting and plantation management. Eighteen forest-habitat species showed declines in plantations (Ramovs and Roberts 2005). Fig. 1 shows our hypotheses of how different harvesting disturbances affect the herbaceous layer. The most severe disturbances, represented in this case by plantations on old fields, remove critical substrates for plants, reduce coarse woody debris, change canopy and litter composition, directly kill many plants, and eliminate propagules. The resulting understory community has low similarity to mature, natural forests.

Another significant product dealing with the herbaceous layer to come out of the Forest Ecology Lab was a book authored by F.S. Gilliam at Marshall University, West Virginia, USA, and me (Gilliam and Roberts 2003). It is the first comprehensive treatment of the herbaceous layer in forests of eastern North America. It includes chapters by various researchers summarizing current knowledge of the herbaceous layer in this region.

As our work on the herbaceous layer progressed, it became obvious that an important determinant of herbaceous-layer response is the nature of the disturbance, particularly its severity (Roberts and Gilliam 2003). I proposed a conceptual model of disturbance severity, which characterizes any disturbance event in terms of the percent of forest canopy and understory vegetation removed, and the percent of forest soil removed or disrupted (Roberts 2004). This model is based on the earlier work of Oliver and Larson (1996), which focused on the dominant tree layer and defined severity in a single dimension. By separating the effects of disturbance on the three principal layers of the forest ecosystem (forest canopy, understory vegetation, and forest floor and soil) into three separate dimensions, the model more accurately describes effects of disturbance. For example, a disturbance that removes the canopy and little understory vegetation, forest floor and soil (e.g., low-impact harvesting to protect natural regeneration) would have very different effects from a disturbance that removes equal amounts of the forest canopy but larger amounts of understory vegetation, forest floor and soil (e.g., harvesting followed by mechanical site preparation). 
Disturbance Type and Severity

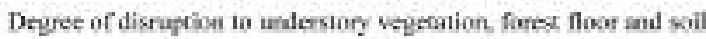

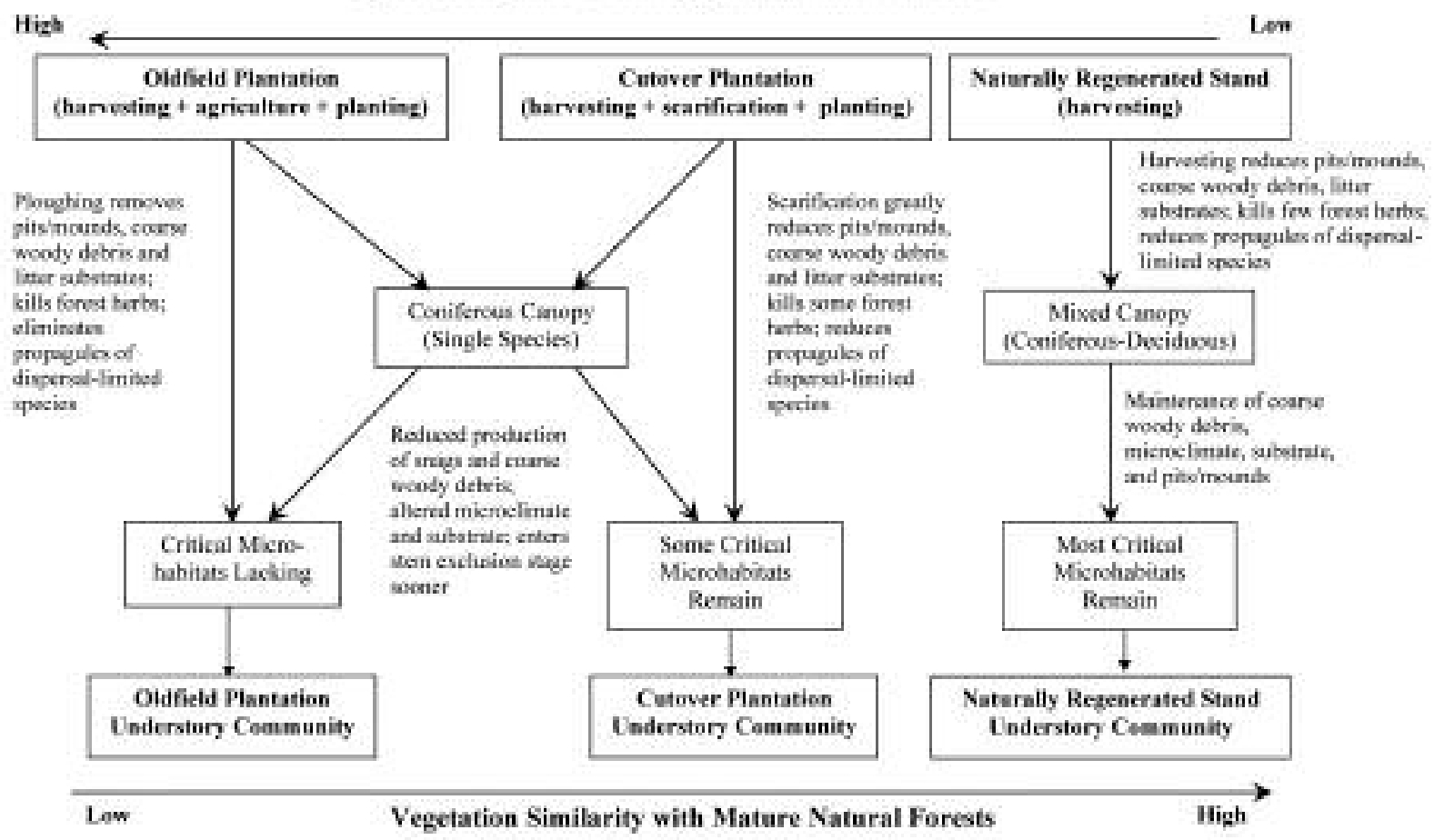

Fig. 1. Model showing how disturbance type and severity affect the understory plant community. Disturbance alters forest structure and environmental conditions that affect the plant community through changes in microhabitat characteristics. Species similarity with mature forests increases from severely disturbed old-field plantations to less severely disturbed young naturally regenerated cutovers. Reprinted from Ecological Applications, vol. 13, B.V. Ramovs and M.R. Roberts, 2003, Understory vegetation and environment responses to tillage, forest harvesting, and conifer plantation development, pp. 1682-1700, with permission from the Ecological Society of America.

I have applied the model to forest harvest disturbance and have placed various silvicultural systems within the threedimensional diagram (Fig. 2; Roberts 2007).

\section{Future Research}

Additional research is needed to properly place silvicultural treatments in the three-dimensional disturbance diagram (Fig. 2). Detailed data on the percent of canopy, understory, and forest floor and soil removed in various silvicultural treatments are rarely available. It would be best to examine treatments that differ dramatically along the three axes of disturbance severity. The disturbance severity model is potentially useful for forest managers to predict impacts of different treatments.

Testing of the accuracy of the disturbance severity model and its ability to predict effects on the herbaceous layer is needed. Mechanisms of herbaceous-layer response to disturbance have not been completely defined. In our work, we have proposed a number of mechanisms that may explain herbaceous-layer response (Roberts and Gilliam 1995, 2003; Ramovs and Roberts 2003, 2005; Roberts 2004); these hypotheses need further testing.
As new techniques of ecosystem management are developed, their impacts on the forest ecosystem must be determined. Current research in the Forest Ecology Lab addresses the effectiveness of leave patches (uncut patches of trees within a harvest block) as refugia for herbaceous-layer species. Leave patches represent one form of variable retention harvesting, which has been proposed to provide elements of habitat for plants and animals in harvested areas (Franklin et al. 1997).

In addition, we are addressing impacts of precommercial thinning on herbaceous species composition. Previous research has been directed toward the final harvest and plantations, but little research has been done on precommercial thinning. In New Brunswick, where a relatively large proportion of the forest area is precommercially thinned, the impacts of this treatment are of concern.

As society's needs and the forest management context continue to evolve over time, so too will forest ecology research evolve to support these needs. As the forester's and conservationist's basic science, forest ecology is the conceptual tool kit for understanding all that we do in the forest environment. 


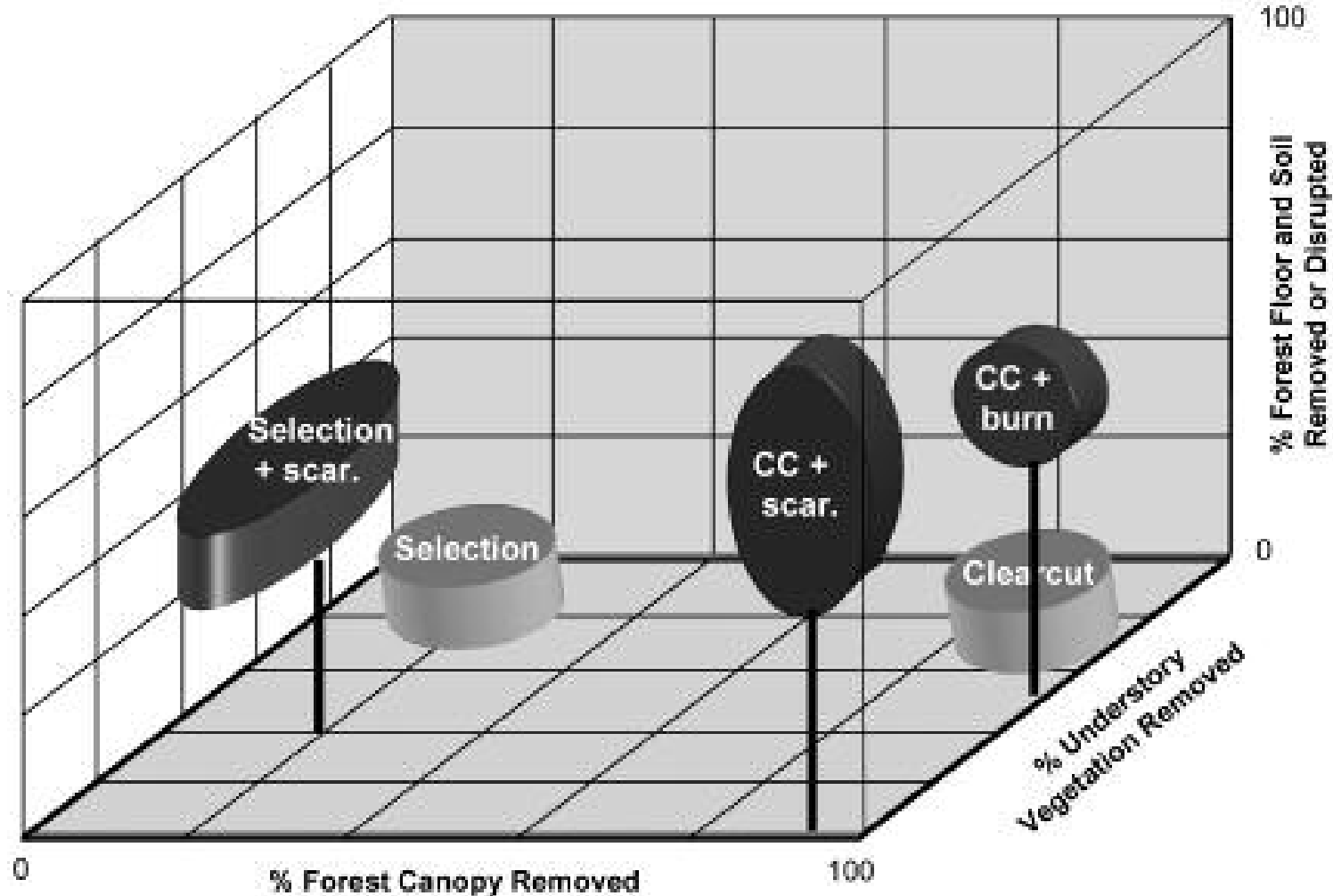

Fig. 2. Conceptual model of disturbance severity on three axes representing the three major vertical layers in the forest ecosystem: forest canopy, understory vegetation, and forest floor and soil. Labelled polygons represent the hypothesized ranges in conditions on these three axes created by different forest harvesting treatments, including: selection system followed by mechanical scarification (Selection + scar.), selection system with no further treatments (Selection), clearcutting followed by mechanical scarification (CC + scar.) and clearcutting with no further treatments (Clearcut). Reprinted from Forest Ecology and Management, vol. 242, M.R. Roberts, 2007, A conceptual model to characterize disturbance severity in forest harvests, pp. 58-64, 2007, with permission from Elsevier.

\section{Acknowledgements}

I gratefully acknowledge the contributions by former graduate students in the Forest Ecology Laboratory, H. Dong, L. Zhu, M. Dijkstra, B. Ramovs, and B. McInnis. Their work provided the basis for the research reviewed in this paper. This paper is dedicated to the memory of my father, Richard Edwin Roberts.

\section{References}

Battles, J.J., A.J. Shlisky, R.H. Barrett, R.C. Heald and B.H. AllenDiaz. 2001. The effects of forest management on plant species diversity in a Sierran conifer forest. For. Ecol. Manage. 146: 211-222.

Betts, M.G. and G.J. Forbes (eds.). 2005. Forest management guidelines to protect native biodiversity in the Greater Fundy Ecosystem. N.B. Cooperative Fish and Wildlife Research Unit, University of New Brunswick, Fredericton. 110 p.

Bowling, C. and V. Zelazny. 1992. Forest site classification in New Brunswick. For. Chron. 68: 34-41.

Burton, P.J., A.C. Balisky, L.P. Coward, S.G. Cumming and D.D. Kneeshaw. 1992. The value of managing for biodiversity. For. Chron. 68: 225-237.

Canadian Council of Forest Ministers (CCFM). 1994. Press release: CCFM ministers reconfirm commitment to sustainable forestry [online]. Available at http://www.ccmf.org/index_e.php [accessed 23 January 2008].
1995. Press release: Canadian framework of criteria and indicators for sustainable forest management [online]. Available at http://www.ccmf.org/index_e.php [accessed 23 January 2008].

2007. Forest Communities Working Group: CCFM final definitions [online]. Available at http://www.ccmf.org/index_e.php [accessed 23 January 2008].

Canadian Forestry Association (CFA). 1992. Forestry on the Hill Special Issue \#3: Biodiversity and monocultures. Canadian Forestry Association, Ottawa. 78 p.

Franklin, J.F., D.R. Berg, D.A. Thornburgh and J.C. Tappeiner. 1997. Alternative silvicultural approaches to timber harvesting: variable retention harvesting systems. In K. Kohm and J.F. Franklin (eds.). Creating a forestry for the 21st Century. pp. 111-139. Island Press, Washington, DC.

Gilliam, F.S. and M.R. Roberts (eds.). 2003. The herbaceous layer in forests of eastern North America. Oxford University Press, New York. $408 \mathrm{p}$.

Godin, B. and M.R. Roberts. 1994. Ecological land classification for New Brunswick: The ecoprovince, ecoregion and ecodistrict levels. NB Dept. Nat. Res. Energy, Fredericton. 99 p.

Kimmins, J.P. 2004. Forest ecology: a foundation for sustainable management and environmental ethics in forestry. 3rd ed. Pearson Prentice Hall, Upper Saddle River. 611 p.

McInnis, B.G. and M.R. Roberts. 1995. Seedling microenvironment in full-tree and tree-length logging slash. Can. J. For. Res. 25: $128-136$. 
Natural Resources Canada (NRCan). 2003. Backgrounder: The Canadian Council of Forest Ministers' framework of criteria and indicators of sustainable forest management, 2003 [online]. Available at http://www.nrcan-rncan.gc.ca/media/archives/newsreleases/2003/200376a_e.htm [accessed 23 January 2008].

Oliver, C.D. and B.C. Larson. 1996. Forest stand dynamics. Update edition. John Wiley \& Sons, New York. 520 p.

Ramovs, B.V. and M.R. Roberts. 2003. Understory vegetation and environment responses to tillage, forest harvesting, and conifer plantation development. Ecol. Appl. 13: 1682-1700.

Ramovs, B.V. and M.R. Roberts. 2005. Response of plant functional groups within plantations and naturally regenerated forests in southern New Brunswick, Canada. Can. J. For. Res. 35: 1261-1276.

Roberts, M.R. 2004. Response of the herbaceous layer to natural disturbance in North American forests. Can. J. Bot. 82: 1273-1283.

Roberts, M.R. 2007. A conceptual model to characterize disturbance severity in forest harvests. For. Ecol. Manage. 242: 58-64.

Roberts, M.R. and H. Dong. 1993. Effects of soil organic layer removal on regeneration after clearcutting a northern hardwood stand in New Brunswick. Can. J. For. Res. 23: 2093-2100.
Roberts, M.R. and F.S. Gilliam. 1995. Patterns and mechanisms of plant diversity in forested ecosystems: implications for forest management. Ecol. Appl. 5: 969-977.

Roberts, M.R. and F.S. Gilliam. 2003. Response of the herbaceous layer to disturbance in eastern forests. In F.S. Gilliam and M.R. Roberts (eds.). The herbaceous layer in forests of eastern North America. pp. 302-320. Oxford University Press, New York.

Roberts, M.R. and L.J. Wuest. 1999. Plant communities of New Brunswick in relation to environmental variation. J. Veg. Sci. 10: 321-334.

Roberts, M.R. and L. Zhu. 2002. Early response of the herbaceous layer to harvesting in a mixed coniferous-deciduous forest in New Brunswick, Canada. For. Ecol. Manage. 155: 17-31.

Society of American Foresters (SAF). 1991. Task force report on biological diversity in forest ecosystems. Society of American Foresters, Bethesda, MD. 52 p. 